\title{
Democracy, Veto Players and the Depth of Regional Integration
}

\author{
Edward D. Mansfield ${ }^{1}$, Helen V. Milner ${ }^{2}$ and Jon C. Pevehouse ${ }^{3}$ \\ ${ }^{1}$ University of Pennsylvania, ${ }^{2}$ Princeton University and ${ }^{3}$ University of Chicago
}

\section{INTRODUCTION}

Q OUNTRIES have developed various types of institutions for coordinating foreign economic policy. Among the most important and pervasive are regional integration arrangements (RIAs). ${ }^{1}$ All RIAs attempt to promote economic integration by improving and stabilising the access that each member has to the other participants' markets. Nonetheless, important differences exist among these arrangements. In a preferential trade arrangement (PTA), member states grant the other participants preferential access to select segments of their market; in a free trade area (FTA), members mutually reduce or eliminate trade barriers on many (if not all) products; in a customs union (CU), members eliminate barriers to trade with other participants and erect a common external tariff (CET) vis-à-vis third parties; in a common market, countries augment a customs union by implementing similar product regulations and by permitting the free flow of factors of production between members; and in an economic union, members participate in a common market and coordinate fiscal and monetary policies. Different types of RIAs aim to achieve different degrees of economic integration among members, with PTAs being the least integrative and economic unions

\footnotetext{
This paper was prepared for a conference on 'The Sequencing of Regional Economic Integration: Issues in the Breadth and Depth of Economic Integration in the Americas', which was held at the Kellogg Institute for International Studies, University of Notre Dame, 9-10 September 2005. It was also presented at seminars at Emory University and the University of Pittsburgh. For helpful comments, we are grateful to David Bearce, Jeffrey Bergstrand, Alexandra Guissinger, Mark Hallerberg, Raymond Robertson and various other seminar and conference participants.

${ }^{1}$ RIAs are so-named because member states are usually located in the same geographical region of the world.
} 
being the most. Very little research, however, has addressed the political economy of why states choose a particular type of integration arrangement. ${ }^{2}$

An extensive literature exists on the economic consequences of integration arrangements (e.g. Lipsey, 1960; de Melo and Panagariya, 1993; Baldwin and Venables, 1995; Bhagwati and Panagariya, 1996; Krueger, 1997; Krishna et al., 1999; Freund, 2000; Panagariya, 2000; Venables, 2003; Lloyd and MacLaren, 2004). Part of this body of research focuses on the economic gains and losses states face as a result of choosing a particular type of RIA. Most of these studies conclude that integration lowers the costs of engaging in overseas trade and may enhance members' welfare, sometimes at the expense of third parties. Notably, the economic benefits for participants tend to rise with the extent of integration embodied in these arrangements, although adjustment costs tend to rise as well.

The political economy of these agreements, however, is less well understood. A few recent studies have attempted to shed light on this issue by analysing the links between interest groups and integration arrangements (e.g. Grossman and Helpman, 1995). But other aspects of domestic politics have received shorter shrift in the literature.

In this paper, we argue that domestic institutions have an important influence on the type of RIA in which states choose to participate. In particular, a country's regime type, its number of institutional 'veto players' and the homogeneity of preferences among those veto players are crucial. The more democratic a country is, the more likely it is to sign any type of integration agreement. However, all democracies are not the same. As the number of veto players rises, democratic governments are increasingly less likely to enter an RIA. A state's regime type and its number of veto players also affect the type of arrangement that it enters. RIAs that aim to achieve greater integration are likely to generate more pronounced distributional consequences than those that aim to achieve less extensive integration. As the number of veto players increases in a democracy, so does the likelihood that at least one such player will have a constituency that is adversely affected by the RIA and that therefore will block it. Consequently, we expect veto players to have a larger effect on the odds of a democracy forming an RIA the greater is the extent of integration that the arrangement aims to achieve. A series of statistical tests, based on an analysis of all pairs of countries from 1950 to 2000 , support our arguments. Democracy and veto players have a strong impact on whether states enter an integration agreement as well as the type of agreement that they select.

${ }^{2}$ Some theoretical and empirical analyses of why states enter RIAs, taken as a whole, are Mansfield et al. (2002) and Mansfield and Reinhardt (2003), which provided political economy explanations, and Baier and Bergstrand (2004), which provided a (pure) economic explanation. 


\section{REGIME TYPE AND THE FORMATION OF INTEGRATION ARRANGEMENTS}

Are democracies more likely than other types of regimes to sign any type of trade agreement? To address this question, we begin by examining first the preferences of political leaders in democratic and non-democratic regimes. Political leaders seek to conclude trade agreements if they think doing so will improve (or at least avoid damaging) their prospects of retaining office. RIAs can promote efficiency; they also enhance the welfare of certain segments of society. These economic gains, however, often come at a political price for leaders. Large increases in integration are likely to affect a wide variety of firms, leaving those in import-competing industries struggling to survive and raising the prospect that workers in these firms will lose their jobs. Moreover, heightened exposure to international markets is likely to redistribute income within society, an outcome that tends to be politically costly for leaders (Fernández and Rodrik, 1991; Rodrik, 1994).

Since leaders depend on the support of constituents to stay in power, adopting policies that antagonise important segments of society is ill advised. However, the means by which leaders retain office depends on the type of political regime. In democracies, leaders must stand for office in regular and competitive elections. In autocracies, by contrast, they must maintain the allegiance of small, select groups within the country, often including the military, labour unions, key members of the ruling party, or owners of the means of production. The groups that choose the leader and keep them in office - sometimes referred to as the 'selectorate' - make up a broader portion of society in a democracy than in an autocracy (Bueno de Mesquita et al., 2003). In most democracies, the selectorate is that portion of the population that is eligible to vote, and the most important member of the selectorate is the median voter, whose ballot determines electoral outcomes.

The need to maintain a certain amount of domestic support is common to all regime types. Consequently, both democratic and autocratic leaders will be reluctant to adopt policies that seem likely to erode their support. Because leaders fear that efficiency-maximising economic policies will adversely affect at least some key constituents, such policies are rarely implemented. Good politics drives out good economics. Trade liberalisation - whether unilateral, bilateral or multilateral - is thus politically infeasible much of the time, since it jeopardises a leader's domestic support among groups that bear adjustment costs or suffer losses in income as a result of heightened exposure to global markets. The interest groups that gain from protection are often powerful and well organised, while those that lose are frequently less influential and poorly organised. ${ }^{3}$ But the likelihood that a country

\footnotetext{
${ }^{3}$ However, some pro-trade groups can be very powerful, especially exporters or multinational firms with widespread global operations (Milner, 1988; Gilligan, 1997).
} 
will be able to adopt more efficient economic policies depends on its regime type. Theory and empirical research have shown that democracies tend to choose more efficient economic policies than other regimes (e.g. Wittman, 1989, 1995; Bueno de Mesquita et al., 2003; Milner with Kubota, 2005).

Following Bueno de Mesquita et al. (2003), Milner with Kubota (2005) and Mayer (1984), we argue that democracies are more likely to enter an RIA than autocracies since democracies have larger selectorates and median voters who benefit more from heightened integration. As Bueno de Mesquita et al. (2003) point out, democratic leaders preserve and expand their domestic support by providing public goods, such as economic growth, whereas autocrats maintain power by furnishing private goods, such as rents from protectionism, that they can distribute to supporters. Societal pressures for private goods provision in autocracies vest leaders of these countries with an incentive to resist entering RIAs that reduce the rents they can provide to supporters. Moreover, such agreements not only encourage member states to liberalise trade with other participants, they also lock leaders into open trade policies. It is harder and more costly for a government to renege on an international trade agreement than it is to unilaterally raise trade barriers because the government faces the prospect that its agreement partners will retaliate. Hence, we expect that autocrats will be reluctant to enter RIAs. Democracies, however, are more likely to prefer agreements that foster trade liberalisation and economic integration, since they promote economic growth. ${ }^{4}$

Furthermore, democratic leaders have an incentive to conclude such agreements because voters have difficulty distinguishing between events that adversely affect the country and are beyond the leader's control and adverse consequences arising from the leader's poor performance in office. As a result, voters may remove a democratic head of state from office because they believe he has done a bad job when in fact he has not performed poorly. Entering an integration arrangement can help chief executives to guard against this possibility, since these institutions are often able to furnish reliable information about the behaviour of member states. Countries that violate their commitments to the institution will trip an alarm sounded by other members or the organisation itself. By publicising a democratic leader's actions, RIAs help him to avoid being turned out of office because voters mistakenly believe he has performed poorly. In non-democracies, by contrast, electoral dynamics are far less important, giving leaders much less incentive to enter integration arrangements (Mansfield et al., 2002). Democracies thus reap benefits from RIAs that autocracies do not; democratic leaders can

${ }^{4}$ A debate exists over how much trade and trade liberalisation foster economic growth. Most observers agree, however, that economic closure and protectionism do not promote growth (e.g. Frankel and Romer, 1999; Rodriguez and Rodrik, 2001; Noguer and Siscart, 2005). 
enhance their political support by signing these agreements while autocrats generally cannot. ${ }^{5}$

\section{THE ROLE OF VETO PLAYERS}

Thus far, we have argued that democratic leaders have a stronger preference for entering RIAs than their autocratic counterparts, largely because they have larger selectorates and therefore face greater pressures to craft policies that benefit the median voter. However, democracies are not homogeneous. There are key differences across democracies that are likely to influence the likelihood of entering an integration arrangement. Of crucial importance in this regard are differences in the formal institutions for sharing decision-making power that create the potential for veto players. These players are institutional and partisan actors whose assent is necessary to change existing policies (Tsebelis, 2002, p. 2). They have an institutional position that allows them to forestall a proposed policy or change in policy and have different preferences about that policy than does the chief executive who proposed it. Tsebelis (2002) shows that the probability of making a change in policy falls as the number of veto players increases, as their preferences diverge, and as the internal coherence of the actors declines. Policy stasis or adherence to the status quo becomes more likely as the number of veto players increases. Others have shown that veto players can affect whether countries liberalise their trade regime or sign RIAs (Frye and Mansfield, 2003; Henisz and Mansfield, 2006; Mansfield et al., 2007).

Veto players exist in all types of regimes. Even in non-democratic systems of government, politics is rarely a pure hierarchy with a unitary decision maker and no veto players. In a dictatorship, the support of the professional military or a political party is frequently necessary for the leader to retain power and implement policies. These groups often exercise veto power over the executive's proposals and may help set the country's policy agenda. In other cases, their acquiescence may be necessary for any policy to be implemented. By definition, democratic systems of government are marked by veto players, although the number of such players varies considerably across democracies. In most democracies, both the legislature and the executive share control over decision making. Sometimes two or more political parties or coalitions compete, and often governments are composed of multiple parties that share control over ministries. Domestic political

\footnotetext{
${ }^{5}$ In some cases, autocratic governments may face a domestic political constellation such that pursuing international economic integration might enhance their domestic support. For instance, if the major groups supporting an autocrat are exporters or large multinational firms, then leaders may choose to adopt policies that promote economic integration. They might, however, still prefer to do this unilaterally rather than in a bilateral or multilateral setting where reneging in the future is harder.
} 
institutions determine how such control is distributed among the actors. For example, constitutions often assign certain powers to the executive and others to the legislature. Formally, democracies will tend to have a greater number than non-democracies since they have meaningful institutions that constrain the power of the leader. However, non-democracies may also have a large number of veto players. We are interested in the actual number of such actors and the homogeneity of their preferences. Conceptually, regime type and veto players are distinct and we treat them as such.

We expect that, among democracies, the likelihood of forming any type of RIA increases as the number of veto players declines. All of these arrangements involve mutual policy adjustment and international cooperation. In each type of arrangement, parties are expected to take steps to provide the other members with improved market access. Such policy changes have distributional consequences. Lowering trade barriers creates groups that gain economically from the policy and groups that lose as a result. When veto players reflect the preferences of distributional losers, altering foreign economic policy and cooperating with other prospective members of the integration arrangement become much more difficult and unlikely. As the number of veto players rises, so does the number of groups they represent and the probability that adversely affected groups are represented by at least one such player. Thus, the chances of ratifying an RIA fall. A larger number of veto players constrains the leader's policy choices and makes it especially difficult to change the status quo policy. The combination of a democracy with a large number of veto players is likely to be very inauspicious for promoting economic integration. This argument is quite consistent with the finding that divided government is an impediment to international cooperation for democracies (Milner, 1997; Milner and Rosendorff, 1997). However, we are unaware of previous efforts to link variations in veto players to the prospects of democracies entering an RIA.

We have less clear expectations about whether or how veto players operate in autocracies. On the one hand, autocrats should be constrained by veto players, just like democratically-elected leaders. Autocrats also need these players to ratify policy change and international agreements. As such, a rise in the number of veto players may increase the likelihood that the distributional losers from a proposed RIA will be represented by such a player and thus reduce the prospects that the arrangement will materialise. On the other hand, autocracies may be more constrained to pursue economically efficient policies as the number of veto players rises. Bueno de Mesquita et al. (2003) point out that, in autocracies, as the 'winning coalition' grows relative to the size of the selectorate, leaders face increasing pressure to provide public rather than private goods. In effect, it becomes too expensive to pay off all of the veto players as their numbers rise; hence autocrats have to switch strategies and behave more like democracies. If they cannot maintain public support through rent seeking, then autocrats may be more likely to choose trade liberalisation and the faster growth associated with 
it as the number of veto players grows. Consequently, it is unclear what effect veto players will have on the likelihood of autocracies entering economic integration agreements.

In sum, then, leaders in democracies have incentives to enter RIAs, both to foster economic growth and to create an institutional alarm that helps reassure the electorate about the leader's competence. We expect, ceteris paribus, that democracies will be more likely to enter regional integration agreements than autocracies. Among democracies, however, the ability of leaders to overcome opposition by the likely losers from these arrangements depends on the number of veto players.

\section{DOMESTIC POLITICS AND THE DEPTH OF INTEGRATION ARRANGEMENTS}

The preceding discussion addressed the effects of regime type and veto players on the formation of RIAs, without distinguishing among different types of arrangements. For a variety of reasons, we expect that the number of veto players will also have a strong influence on the type of integration arrangement that a democratic state enters. The magnitude of domestic change needed to comply with an RIA and the associated political costs borne by leaders for entering it depend on the extent of integration that the agreement aims to achieve. As the proposed degree of economic integration rises, so do the expected adjustment costs for adversely affected domestic actors. As the number of veto players rises, so does the likelihood that adversely affected groups are represented by at least one veto player. These players are increasingly likely to resist policy change as their key constituents bear higher costs stemming from that change. In this section, we explain why increasing the proposed level of integration is likely to involve larger adjustment costs, raising the likelihood that veto players will expend the effort to block such arrangements.

RIAs that aim to achieve greater economic integration also tend to entail heightened political integration among members. Domestic legislatures lose the authority to set trade policy and are stripped of policy mechanisms that can be used to pressure foreign or domestic executives. Once a state decides to enter a $\mathrm{CU}$, its trade barriers on the products of third parties are replaced with a common external tariff negotiated at the supranational level. In common markets and economic unions, issues such as monetary policy as well as labour and immigration policy are also handled by international institutions that may or may not be responsive to the domestic politics of member states. ${ }^{6}$ Thus, the effectiveness of institutional veto players in blocking policy change can be mitigated by RIAs if policy making shifts from the domestic to the supranational level. Moreover, the

\footnotetext{
${ }^{6}$ A new body of research in international relations suggests agency slack is a major problem for members of international organisations. See Hawkins et al. (2006).
} 
ability of veto players to influence policy becomes increasingly attenuated as the RIA aims to achieve progressively deeper integration. This effect is quite separate from the effects of societal interests (which we turn to below), but stems from the institutions that give voice to those interests, who may themselves oppose a loss of autonomy.

There are various reasons why deeper economic integration is likely to spur opposition to RIAs among certain segments of society. As the proposed level of integration deepens, the number of actors affected is likely to rise considerably. Arrangements that envision more extensive integration are likely to cover more goods and services - and therefore to affect more sectors and a larger segment of society - than other RIAs. With the adoption of a CET, moreover, the prospect of a sector in a given member state obtaining protection against imports from third parties declines as well. Similarly, moving from a PTA or an FTA to a CU, a common market or an economic union increases the variety of issues that are covered by the arrangement (from trade to finance and immigration, among others) and the odds that additional domestic groups will face sizeable adjustment costs. Thus, as the breadth of the issues covered by a proposed RIA rises, so too does the likelihood that a significant portion of society will anticipate being adversely affected and therefore oppose entering the arrangement.

Furthermore, there is reason to believe that as the number of sectors covered by a proposed RIA expands, so will the effort expended by the likely distributional losers to block membership. Under FTAs, increased competition from partner countries will lead to contraction of non-competitive industries (Hillman, 1982; Long and Vousden, 1991; Richardson, 1993). As a result, workers in these industries will be displaced and the industries' 'lobbying activities decrease and the level of protection from non-members granted [them] by policy-makers also decreases' (Richardson, 1993, p. 320; see also Cassing and Hillman, 1986). If individuals affiliated with such industries anticipate that the FTA will threaten their employment and hamper their ability to lobby, then they have reason to exert considerable effort to block the formation of the FTA in the first place.

It is even harder to successfully lobby for changes in trade policy within a CU than within an FTA. Since the former involves the adoption of a CET, an industry can no longer influence trade policy by lobbying its home government alone. The industries that would be adversely affected by the CET or the heightened integration of members' markets should fight particularly hard to block a CU. It is, of course, possible that these industries may find allies in other member states, raising the possibility that they could join forces to lobby for a higher CET. However, these efforts are likely to be frustrated by free-riding. The likely consequence, as Panagariya and Findlay (1996) and Richardson (1994) have shown, is that the level of external protection will actually be lower in a CU than in an FTA. A domestic industry will assume that its foreign counterparts will lobby hard for a higher CET and therefore will reduce its own lobbying efforts. Since 
all industries are likely to behave in this way, the likely result is less lobbying within the $\mathrm{CU}$ and a lower level of protection. Foreseeing this possibility, industries will attempt to scale back integration goals. As Richardson (1994, p. 88) points out, "just as firms lobby for tariff levels, presumably they also lobby for their preferred arrangement'.

For these reasons, increasing the number of veto players in a democracy is likely to more substantially reduce the prospect of forming an RIA as the extent of proposed integration rises. Heightened integration tends to reduce the decisionmaking power of certain veto players (such as domestic legislatures), increase the adjustment costs and the portion of society affected, and attenuate the ability of domestic groups to lobby the government. As the number of veto players increases, so does the odds that at least one player will represent an adversely affected group. And as the proposed level of integration rises and likely losses to adversely affected groups therefore mount, veto players have reason to oppose an RIA with increasing intransigence.

Some studies have made arguments similar to ours. Richardson (1993, pp. 31011) claims a key puzzle left by the endogenous protection literature concerns why domestic pressure groups allow the formation of deeper integration arrangements in the first place. His answer focuses on pressure groups and domestic political institutions: 'the entry of countries into new bilateral or multilateral trade agreements is very often triggered by underlying shifts in political power or support' (Richardson, 1993, p. 319). Or as Long and Vousden (1991, p. 94, fn. 7) argue, entry into an RIA 'might simply reflect such things as the balance of powers in the constitution and the delineation of electoral boundaries'. For example, in a study of the US-Canadian FTA, Hufbauer (1989, p. 143) suggests that the Canadian elections of 1988, which cemented the power of the conservative Mulroney government, were key to the agreement's ratification.

Indeed, this is the crux of the empirical tests that we conduct in the remainder of this paper. We expect that as the number of constitutionally mandated veto players increases in democracies and as their preferences diverge, deeper integration agreements are less likely to be signed. But why is it that RIAs are not simply designed in such a way that the demands of veto players are woven into the fabric of the institution? Why not assume that rather than oppose integration entirely, veto players will simply attempt to achieve an arrangement that protects their interests?

Two factors make this outcome unlikely. First, institutional factors may limit the input that societal groups have on the design of a trade pact. For example, fast-track authority in the US allows Congress to accept or reject a pact, but without altering the terms of the arrangement. While it might be possible for an executive to negotiate an agreement taking into account the objections of many relevant veto players, this is increasingly unlikely as the number of veto players increases, since the sheer number of demands in such negotiations would become enormous. Second, as Schiff (2000, p. 11) argues, while FTAs leave room for 
domestic groups to manipulate tariff rates and other trade policies, such manipulation becomes increasingly difficult as the proposed level of integration rises. Within FTAs, for example, countries often negotiate exceptions and rules of origins, but one purpose of heightened integration is to decrease exceptions and expand the authority granted to supranational institutions, severely limiting the ability of executives (or any negotiators) to design a trade pact that meets the demands of any particular veto player.

\section{A STATISTICAL MODEL}

Having laid out our argument, we now introduce the variables and methods that are used to test it. These tests centre on estimating the following model:

$$
\begin{aligned}
\text { Proposed Integration }_{i j}= & \beta_{0}+\beta_{1} \text { Veto Players }_{i}+\beta_{2} \text { Veto Player }_{j}+\beta_{3} \text { Regime Type }_{i} \\
& +\beta_{4} \text { Regime Type }_{j}+\beta_{5}\left(\text { Veto Player }_{i} \times \text { Regime Type }_{i}\right) \\
& +\beta_{6}\left(\text { Veto Player }_{j} \times \text { Regime Type }_{j}\right)+\beta_{7} \text { Trade }_{i j}+\beta_{8} \text { GDP }_{i} \\
& +\beta_{9} \text { GDP }_{j}+\beta_{10} \Delta G D P_{i}+\beta_{11} \Delta \text { GDP }_{j}+\beta_{12} \text { Dispute }_{i j} \\
& +\beta_{13} \text { Ally }_{i j}+\beta_{14} \text { Former Colony }_{i j}+\beta_{15} \text { Contiguity }_{i j} \\
& +\beta_{16} \text { Distance }_{i j}+\beta_{17} \text { Hegemony }+\beta_{18} \text { GATT }_{i j}+\varepsilon .
\end{aligned}
$$

The dependent variable is the proposed level of integration in an RIA signed by a pair of states, $i$ and $j$, in year $t+1$. We code this variable on a six-point ordinal scale. It equals zero if states $i$ and $j$ did not form an integration arrangement in year $t+1$, one if they formed a PTA, two if they created an FTA, three if they established a customs union, four if they entered a common market, and five if they joined an economic union. Note that the observed value of this variable is non-zero only when states initially join an RIA, not in subsequent years when the agreement is in force. ${ }^{7}$ We draw our sample of arrangements primarily from the World Trade Organization (1995), but also include arrangements that were not notified to either this organisation (WTO) or its predecessor, the General Agreement on Tariffs and Trade (GATT), since there is no reason to believe that regime type or veto players influence the decision to enter only those RIAs notified to these bodies. ${ }^{8}$

\footnotetext{
${ }^{7}$ We do not exclude dyad years in which an agreement is in force for two reasons. First, some country-pairs form more than one arrangement during the period covered here. Second, some RIAs are upgraded - for example, from an FTA to a CU or a common market. Later, however, we analyse the sensitivity of our results to this coding decision.

${ }^{8}$ We draw data on RIAs that were not notified to either GATT or the WTO from Mansfield and Pevehouse (2000).
} 
The coding of these agreements is based on an analysis of each RIA. Some arrangements set integration goals that are not realised, but we are interested in the goals of the treaty itself. If, for example, states decide to enter a common market, they likely have every hope and expectation that the market will come to fruition even if that does not actually occur. Moreover, domestic interests are more likely to respond to the proposed level of integration than to an ad hoc calculation about the level of integration that will eventually be achieved. In our dataset, common markets are the most frequently adopted form of RIA: 1,067 dyads form this type of arrangement. FTAs are formed by 683 dyads, CUs are established by 228 dyads, and PTAs are created by 136 dyads. Economic unions are the rarest type of integration arrangement, having been established by only 88 country-pairs. ${ }^{9}$

The first six independent variables in equation (1) are included to test our

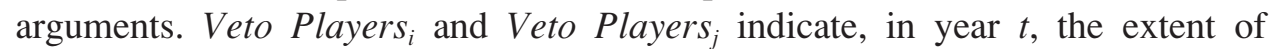
constitutionally mandated institutions that can exercise veto power over decisions in states $i$ and $j$, as well as the alignment of actors' preferences between those institutions within each state. The data are taken from Henisz (2002), who measures the presence of effective branches of government outside the executive's control, the extent to which these branches are controlled by the same political party as the executive, and the homogeneity of preferences within these branches. As he notes, the measure

draws from recent theoretical developments in positive political theory to develop a structurally derived and internationally comparable measure of the degree of constraints on policy change using data on the number of independent veto points in the political system (executive, legislative, judicial and sub-federal branches of government) and the distribution of political preferences both across and within these branches (Henisz, 2000, p. 5).

Henisz's measure is particularly well-suited to testing our argument. It is theoretically derived from a single-dimensional, spatial model of policy choice that allows the status quo and the preferences of veto players to vary across the entire space. As such, this measure corresponds closely to how we view a veto player. Moreover, the measure's single policy dimension conforms to our focus on trade policy. Henisz (2002, p. 363) finds that

(1) each additional veto point (a branch of government that is both constitutionally effective and controlled by a party different from other branches) provides a positive but diminishing effect on the total level of constraints on policy change and (2) homogeneity (heterogeneity) of party preferences within an opposition (aligned) branch of government is positively correlated with constraints on policy change.

\footnotetext{
${ }^{9}$ We exclude non-reciprocal agreements, since these arrangements do not require policy adjustments from all members. Thus, veto players are less likely to play a role in non-reciprocal agreements since some participants bear few costs for entering the arrangement. Nonetheless, including these agreements in the dataset changes very few of our results.
} 
The resulting measure is a continuous variable ranging from 0 to 1 . When Veto Players $_{i}$ or Veto Players $j_{j}$ equals 0 , there are no veto players in states $i$ or $j$, respectively. Higher values indicate the presence of effective branches of government to balance the chief executive. In cases where effective branches exist, these variables take on larger values as party control across some or all of these branches diverge from the executive's party. For example, in the US, the value of this index increases during periods of divided government. ${ }^{10}$ Because of this variable's theoretically-based construction and its attention to both domestic institutional arrangements and the preferences within those arrangements, it is especially useful for testing our argument. ${ }^{11}$

This measure of veto players is not derived to analyse trade policy in particular. However, developing a measure that is specific to foreign economic policy would be very difficult. Furthermore, doing so would leave us open to the charge that we had constructed the variable in a way that supports our argument, and it is not clear that a measure of veto players for trade policy would be much different from Henisz's more general measure. For the most part, changes in trade policy are subject to the same institutional hurdles and ratification processes that all other policies face. In the US, for example, trade policy initiatives have been contested by the US Congress and the President, both of which have the ability to block policy change. Fast track, the procedure often used to move trade legislation forward, simply reduces Congress's ability to amend a trade agreement; it does not change the fact that a majority in both houses must ratify that policy change. Veto players influence the ratification of changes in policy. Trade agreements tend to require changes in policy in most countries and thus to invoke the usual institutional veto players.

A second key variable needed to test our hypothesis is the regime type of each state. Regime Type $_{i}$ and Regime Type $e_{j}$ are 21-point indices of country $i$ 's and country $j$ 's regime type in year $t$. These widely-used variables are constructed using the Polity dataset. They take on values ranging from 1 for the most

\footnotetext{
${ }^{10}$ For more details concerning this measure of veto players, see Henisz $(2000,2002)$. Note that we use the variant of this measure that excludes the judiciary, since trade policy change does not typically involve such agents. Nonetheless, our results are not sensitive to this decision.

${ }^{11}$ Henisz's measure has some advantages compared to alternative measures of veto players. For example, Beck et al. (2001) have developed a measure that emphasises the electoral rules and the degree of electoral competition in a country, as well as the degree of partisan differences across these players. This measure, however, is available for fewer countries than Henisz's measure and it only covers the period from 1975 onward. Using the Beck et al. measure rather than Henisz's measure cuts the size of our sample in half, which is clearly undesirable. However, there is a good deal of agreement between Henisz's measure and Beck et al.'s measure where those samples overlap - the correlation between a country's annual score on Henisz's measure of veto players and its score on the Beck et al. measure is about 0.75, suggesting that our results are not driven by the choice of measure.
} 
autocratic states to 21 for the most democratic countries (Jaggers and Gurr, 1995). ${ }^{12}$

Crucial to testing our argument is the interaction between Regime Type and $V e t o$ Points. We expect that an increase in the number of veto players will reduce the likelihood of democratic states forming an RIA, and that this effect will be larger as the proposed level of integration in the RIA rises. As such, the coefficient of each interaction term should be negative.

Very few empirical studies have addressed the factors influencing the proposed level of integration in RIAs. Nonetheless, we include in equation (1) a variety of variables that previous studies have linked to the formation of these arrangements (taken as a whole) to ensure that they do not account for any observed relationship between either veto players or regime type and our dependent variable. Trade $e_{i j}$ is the logarithm of the total value of trade (in constant 1995 US dollars) between countries $i$ and $j$ in year $t$. Some studies conclude that extensive international trade linkages prompt groups within society that benefit as a result to press governments to enter RIAs, since these arrangements reduce the prospect of a future breakdown in trade relations among member states (e.g. Nye, 1988). Moreover, heightened overseas commerce can increase the susceptibility of firms to predatory behaviour by foreign governments, prompting firms to call for the formation of RIAs that limit the ability of governments to behave opportunistically (Yarbrough and Yarbrough, 1992). ${ }^{13}$ There is also reason to believe that as trade flows increase, various economic actors may lobby for further economic coordination between states, deepening the proposed level of integration within an RIA.

In addition to economic relations between countries, domestic economic conditions are likely to influence the decision to join an RIA and the proposed depth of integration within the arrangement. Particularly important in this regard is a state's economic size and its rate of economic growth. Large states may have less incentive to seek the expanded market access afforded by RIA membership than their smaller counterparts. These larger markets may also have less reason to seek arrangements that foster more extensive integration. We therefore analyse $G D P_{i}$ and $G D P_{j}$, the logarithm of country $i$ 's and country $j$ 's gross domestic products (in constant 1995 US dollars) in year $t$. Moreover, fluctuations in economic growth may affect whether states enter integration arrangements. On the one hand, some research indicates that downturns in the business cycle lead states to seek membership in such arrangements (Mattli, 1999). On the other hand, increased growth is likely to increase a country's demand for imports and supply of exports,

\footnotetext{
${ }^{12}$ We use Gleditsch's (2004) update of the Polity IV dataset (Marshall, 2004), which includes data on smaller states excluded by the Polity project, but included in the Correlates of War Project list of nation-states.

${ }^{13}$ We use Gleditsch's (2002) data on trade flows. Gleditsch draws much of his data from the International Monetary Fund's Direction of Trade Statistics. Like the IMF data, however, Gleditsch's data are in current dollars. We deflate these data using the US consumer price index.
} 
creating an incentive to gain preferential access to overseas markets and perhaps to enter RIAs that propose deeper integration. To address this issue, we introduce $\triangle G D P_{i}$ and $\triangle G D P_{j}$, the changes in $G D P_{i}$ and in $G D P_{j}$ from $t-1$ to $t{ }^{14}$

Political relations between states are also likely to influence whether they join the same RIA, as well as the proposed depth of integration in those arrangements. Military hostilities between states may discourage economic cooperation and thus their propensity to sign an RIA. Similarly, political-military alliances may promote economic cooperation, as Gowa (1994) has argued. Dispute $e_{i j}$ is coded 1 if countries $i$ and $j$ are involved in a militarised interstate dispute (MID) during year $t$, and 0 otherwise. ${ }^{15} A l l y_{i j}$ equals 1 if countries $i$ and $j$ are members of a military alliance in year $t$, and 0 otherwise. Since previous research on economic regionalism has found that a former colonial relationship between $i$ and $j$ increases the likelihood that they will enter the same RIA, we also include Former Colony $i j$, a dummy variable that equals 1 if countries $i$ and $j$ had a colonial relationship ending after the Second World War (Mansfield et al., 2002). ${ }^{16}$ These political factors have been linked to the onset of RIAs, but they may also affect the type of arrangement a pair of states join. For example, states marked by cooperative political relations (that is, those that are not embroiled in a dispute and those that are political-military allies) may be much more willing to coordinate economic policies and extensively integrate their economies than states with antagonistic relations.

Geographical distance is another important influence on RIA membership and one that might affect the proposed depth of integration as well. States often enter RIAs to obtain preferential access to their key trade partners' markets. These partners tend to be located nearby, since closer proximity reduces transportation costs and other impediments to trade. It is unclear, however, whether proximity also influences the type of integration arrangement that states select. To address this issue, we introduce two variables: Contiguity $i j$ is coded 1 if countries $i$ and $j$ share a common border, 0 otherwise; Distance $_{i j}$ is the logarithm of the capital-tocapital distance between $i$ and $j .{ }^{17}$

In addition, conditions throughout the international system are likely to affect the prospects of RIA formation. Many studies have found that declining hegemony contributes to the proliferation of integration arrangements (Bhagwati, 1993; Krugman, 1993; Mansfield, 1998). It may also be the case that declining hegemony spurs states to seek deeper levels of integration since they fear that multilateral

\footnotetext{
${ }^{14}$ GDP data are also taken from Gleditsch (2002) and are deflated using the US consumer price index.

${ }^{15}$ For a description of the MIDs data, see Jones et al. (1996). For a review of the updated MIDs data, see Ghosn and Palmer (2003).

${ }^{16}$ Data on former colonial relations are taken from Kurian (1992). Data on alliances are taken from the Correlates of War Project (Gibler and Sarkees, 2003).

${ }^{17}$ Data on distance and contiguity are taken from Oneal and Russett (1999).
} 
coordination of tariff rates and monetary policy, for example, will erode. We therefore include Hegemony, the proportion of global GDP produced by the state with the largest national income (which, in our sample, is always the US) in year $t$. This variable therefore takes on the same value for each country in $t$.

Further, members of the GATT/WTO have reason to enter RIAs as a means of gaining bargaining power within the multilateral trade regime (Mansfield and Reinhardt, 2003). Consequently, we introduce $G A T T_{i j}$ in the model. It equals 1 if countries $i$ and $j$ are both members of GATT in each year, $t$, prior to 1995 or if they are both members of the WTO in years from 1995 on, and 0 otherwise. ${ }^{18}$ Finally, $\varepsilon$ is a stochastic error term.

Descriptive statistics for all of the variables are presented in Table 1. The sample in the following analyses is comprised of all pairs of states during the period from 1950 to 1999 (years $t$ ). Which state is $i$ in each pair and which one is $j$ is determined by random assignment. Because the observed value of the dependent variable is ordered, we use an ordered probit specification to estimate the model.

TABLE 1

Descriptive Statistics

\begin{tabular}{|c|c|c|c|c|}
\hline Variable & Mean & S.D. & Minimum & Maximum \\
\hline Proposed Integration & 0.025 & 0.281 & 0 & 5 \\
\hline (ln) Trade & -1.350 & 4.918 & -6.908 & 12.492 \\
\hline Regime Type $_{i}$ & 0.331 & 0.471 & 0 & 1 \\
\hline Regime Type $_{j}$ & 0.332 & 0.471 & 0 & 1 \\
\hline Veto Players & 0.175 & 0.213 & 0 & 0.708 \\
\hline Veto Players & 0.177 & 0.213 & 0 & 0.708 \\
\hline Veto Players $_{i} \times$ Regime $_{i}$ & 0.135 & 0.207 & 0 & 0.708 \\
\hline Veto Players $_{j} \times$ Regime $_{j}$ & 0.136 & 0.207 & 0 & 0.708 \\
\hline (ln) $G D P_{i}$ & 17.178 & 1.797 & 13.099 & 22.870 \\
\hline (ln) $G D P_{i}$ & 17.182 & 1.795 & 13.099 & 22.870 \\
\hline$\Delta G D P_{i}$ & $5,564,673$ & $2.43 e+07$ & $-1.61 e+08$ & $4.06 \mathrm{e}+08$ \\
\hline$\Delta G D P_{j}^{l}$ & $5,594,755$ & $2.43 e+07$ & $-1.61 \mathrm{e}+08$ & $4.06 \mathrm{e}+08$ \\
\hline Hegemony & 0.220 & 0.018 & 0.201 & 0.276 \\
\hline Dispute & 0.005 & 0.071 & 0 & 1 \\
\hline (ln) Distance & 8.220 & 0.783 & 1.872 & 9.423 \\
\hline Ally & 0.073 & 0.261 & 0 & 1 \\
\hline Former Colony & 0.004 & 0.063 & 0 & 1 \\
\hline Contiguity & 0.038 & 0.190 & 0 & 1 \\
\hline GATT & 0.343 & 0.475 & 0 & 1 \\
\hline
\end{tabular}

Notes:

$N=339,910$ for all variables. S.D. $=$ standard deviation.

${ }^{18}$ Data are taken from the WTO website: http://www.wto.org. 


\section{RESULTS}

The first column of Table 2 presents the initial parameter estimates. The coefficient estimates of Veto Players $s_{i}$,Veto Players , Regime Type $_{i}$ and Regime Type R $_{j}$ are positive; the estimates of Veto Players ${ }_{i} \times$ Regime Type $_{i}$ and Veto Players ${ }_{j} \times$ Regime Type $e_{j}$ are negative, and each of these estimates is statistically significant. These results indicate that as the number of veto players rises in more democratic states, the level of proposed integration declines.

In order to assess the substantive significance of these results, we calculate the predicted probability of two democracies (which, for present purposes, we define as countries whose regime type score is 21) forming each type of RIA analysed here when the values of Veto Players ${ }_{i}$ and Veto Players $_{j}$ are at the 90th percentile found in the data, and again when they are at the 10th percentile. Moving from the higher to the lower value of veto players yields a nearly 10 -fold increase in the predicted probability of forming a PTA, representing a rise from less than one dyad forming a PTA per year to more than five dyads. This change yields almost an 11-fold increase in the predicted probability of establishing an FTA, representing a shift from less than three dyads forming such an arrangement to roughly 30; it generates a 12 -fold rise in the likelihood of forming a customs union, representing a change from about one dyad entering a $\mathrm{CU}$ to more than 11 ; it produces a more than 15 -fold jump in the prospect of entering a common market, representing a shift from slightly more than two dyads creating a common market to almost 40; and it leads to more than a 32 -fold increase in the predicted probability of creating an economic union, representing a change from virtually no dyads forming such a union to about two. ${ }^{19}$ These results strongly support our argument that democracies are more likely to enter integration agreements as the number of veto players declines and that the effect of veto players is quantitatively larger for arrangements that propose more extensive integration.

Our results also show that, within the range of veto players that is observed for both democracies and autocracies, democracies are more likely than autocracies (which, for present purposes, we define as countries whose regime type score is 1) to form integration arrangements. When evaluating the lowest value of veto players that occurs in the data for both democracies and autocracies, the predicted probability of forming a PTA is nearly 14-fold higher for democracies than for autocracies. ${ }^{20}$ For FTAs, the probability is 15 -fold higher in democracies; for customs unions, it is 17 -fold higher; for common markets, it is over 25 -fold

\footnotetext{
${ }^{19}$ We calculate these numbers by multiplying the predicted probability by the number of dyads, divided by the number of years in the sample.

${ }^{20}$ For the purposes of identifying the range of veto players that occur in the data for both democracies and autocracies, we follow some previous studies in identifying democracies as countries with a regime type score that exceeds 17 and autocracies as countries with a regime type score less than 5 .
} 
TABLE 2

Ordered Probit Estimates of the Effects of Veto Players and Regime Type on the Depth of Regional Integration, 1950-2000

\begin{tabular}{|c|c|c|c|c|}
\hline & Base Model & $\begin{array}{l}\text { PTA } \\
\text { Instrument }\end{array}$ & $\begin{array}{l}\text { Regime } \\
\text { Indicator }^{\mathrm{a}}\end{array}$ & $\begin{array}{l}\text { Democracies } \\
\text { Only }\end{array}$ \\
\hline Veto Players $_{i}$ & $\begin{array}{l}1.073 * * \\
(0.163)\end{array}$ & $\begin{array}{l}1.012 * * \\
(0.165)\end{array}$ & $\begin{array}{l}0.314 * * \\
(0.091)\end{array}$ & $\begin{array}{c}-0.637 * * \\
(0.135)\end{array}$ \\
\hline Veto Players & $\begin{array}{l}0.892 * * \\
(0.171)\end{array}$ & $\begin{array}{l}0.841 * * \\
(0.173)\end{array}$ & $\begin{array}{c}0.143 \\
(0.094)\end{array}$ & $\begin{array}{c}-0.376^{* *} \\
(0.133)\end{array}$ \\
\hline Regime Type $_{i}$ & $\begin{array}{l}0.029 * * \\
(0.002)\end{array}$ & $\begin{array}{l}0.034 * * \\
(0.002)\end{array}$ & $\begin{array}{l}0.399 * * \\
(0.038)\end{array}$ & - \\
\hline${\text { Regime } \text { Type }_{j}}$ & $\begin{array}{l}0.024 * * \\
(0.002)\end{array}$ & $\begin{array}{l}0.029 * * \\
(0.002)\end{array}$ & $\begin{array}{l}0.282 * * \\
(0.040)\end{array}$ & - \\
\hline $\begin{array}{r}{\text { Regime } \text { Type }_{i} \times} \times \\
\text { Veto Players }\end{array}$ & $\begin{array}{c}-0.103^{* *} \\
(0.009)\end{array}$ & $\begin{array}{c}-0.108^{* *} \\
(0.009)\end{array}$ & $\begin{array}{c}-1.171^{* *} \\
(0.130)\end{array}$ & - \\
\hline $\begin{array}{r}{\text { Regime } \text { Type }_{j} \times} \times \\
\text { Veto Players }\end{array}$ & $\begin{array}{c}-0.093 * * \\
(0.010)\end{array}$ & $\begin{array}{c}-0.099 * * \\
(0.010)\end{array}$ & $\begin{array}{c}-0.881^{* *} \\
(0.136)\end{array}$ & - \\
\hline Trade $_{i j}$ & $\begin{array}{c}-0.001 \\
(0.003)\end{array}$ & $\begin{array}{c}-0.002 \\
(0.003)\end{array}$ & $\begin{array}{c}-0.002 \\
(0.003)\end{array}$ & $\begin{array}{r}-0.010 \\
(0.007)\end{array}$ \\
\hline$G D P_{i}$ & $\begin{array}{c}-0.067 * * \\
(0.006)\end{array}$ & $\begin{array}{c}-0.087 * * \\
(0.006)\end{array}$ & $\begin{array}{c}-0.067 * * \\
(0.006)\end{array}$ & $\begin{array}{c}-0.006 \\
(0.013)\end{array}$ \\
\hline$G D P_{j}$ & $\begin{array}{c}-0.060 * * \\
(0.006)\end{array}$ & $\begin{array}{l}-0.077 * * \\
(0.006)\end{array}$ & $\begin{array}{l}-0.060 * * \\
(0.006)\end{array}$ & $\begin{array}{c}-0.017 \\
(0.013)\end{array}$ \\
\hline$\Delta G D P_{i}$ & $\begin{array}{c}8.71 \times 10^{-10 *} \\
\left(3.93 \times 10^{-10}\right)\end{array}$ & $\begin{array}{c}1.15 \times 10^{-9} * * \\
\left(4.04 \times 10^{-10}\right)\end{array}$ & $\begin{array}{c}7.64 \times 10^{-10} \\
\left(4.10 \times 10^{-10}\right)\end{array}$ & $\begin{array}{c}5.38 \times 10^{-9} \\
\left(5.02 \times 10^{-10}\right)\end{array}$ \\
\hline$\Delta G D P_{j}$ & $\begin{array}{c}6.70 \times 10^{-10} \\
\left(3.68 \times 10^{-10}\right)\end{array}$ & $\begin{array}{c}9.43 \times 10^{-10 *} \\
\left(3.81 \times 10^{-10}\right)\end{array}$ & $\begin{array}{c}5.72 \times 10^{-10} \\
\left(3.81 \times 10^{-10}\right)\end{array}$ & $\begin{array}{r}9.40 \times 10^{-9 *} \\
\left(4.12 \times 10^{-10}\right)\end{array}$ \\
\hline Dispute $_{i j}$ & $\begin{array}{l}-0.166 \\
(0.104)\end{array}$ & $\begin{array}{l}-0.223 * \\
(0.097)\end{array}$ & $\begin{array}{l}-0.143 \\
(0.104)\end{array}$ & $\begin{array}{l}-0.119 \\
(0.293)\end{array}$ \\
\hline Ally $_{i j}$ & $\begin{array}{l}0.499 * * \\
(0.025)\end{array}$ & $\begin{array}{l}0.628 * * \\
(0.024)\end{array}$ & $\begin{array}{l}0.507 * * \\
(0.025)\end{array}$ & $\begin{array}{l}0.272^{* *} \\
(0.045)\end{array}$ \\
\hline Former Colony $_{i j}$ & $\begin{array}{c}-0.294 \\
(0.221)\end{array}$ & $\begin{array}{c}-0.287 \\
(0.227)\end{array}$ & $\begin{array}{c}-0.287 \\
(0.223)\end{array}$ & $-^{\mathrm{b}}$ \\
\hline Contiguity $_{i j}$ & $\begin{array}{c}-0.071 \\
(0.039)\end{array}$ & $\begin{array}{c}-0.050 \\
(0.032)\end{array}$ & $\begin{array}{c}-0.061 \\
(0.039)\end{array}$ & $\begin{array}{c}-0.092 \\
(0.072)\end{array}$ \\
\hline Distance $_{i j}$ & $\begin{array}{c}-0.383 * * \\
(0.015)\end{array}$ & $\begin{array}{c}-0.480 * * \\
(0.013)\end{array}$ & $\begin{array}{c}-0.375 * * \\
(0.015)\end{array}$ & $\begin{array}{c}-0.341 * * \\
(0.025)\end{array}$ \\
\hline Hegemony & $\begin{array}{c}-10.117 * * \\
(0.611)\end{array}$ & $\begin{array}{c}-12.626^{* * *} \\
(0.668)\end{array}$ & $\begin{array}{c}-10.107 * * \\
(0.616)\end{array}$ & $\begin{array}{l}-3.641^{* *} \\
(1.002)\end{array}$ \\
\hline$G A T T_{i j}$ & $\begin{array}{l}0.156^{* * *} \\
(0.019)\end{array}$ & $\begin{array}{l}0.192 * * \\
(0.017)\end{array}$ & $\begin{array}{l}0.161 * * \\
(0.019)\end{array}$ & $\begin{array}{l}0.180 * * \\
(0.045)\end{array}$ \\
\hline Instrument[RIA] & - & $\begin{array}{c}-4.246^{* *} \\
(0.315)^{\mathrm{c}}\end{array}$ & - & - \\
\hline _Cut 1 & $\begin{array}{l}-4.424 * * \\
(0.266)\end{array}$ & $\begin{array}{c}-6.305^{* *} \\
(0.290)\end{array}$ & $\begin{array}{l}-4.604 * * \\
(0.269)\end{array}$ & $\begin{array}{l}-1.727 * * \\
(0.524)\end{array}$ \\
\hline -Cut 2 & $\begin{array}{c}-4.398 * * \\
(0.266)\end{array}$ & $\begin{array}{c}-6.279 * * \\
(0.290)\end{array}$ & $\begin{array}{c}-4.578 * * \\
(0.269)\end{array}$ & $\begin{array}{c}-1.718^{* *} \\
(0.523)\end{array}$ \\
\hline _Cut 3 & $\begin{array}{c}-4.241 * * \\
(0.266)\end{array}$ & $\begin{array}{c}-6.121^{* * *} \\
(0.290)\end{array}$ & $\begin{array}{c}-4.423^{* *} \\
(0.268)\end{array}$ & $\begin{array}{c}-1.421^{* *} \\
(0.525)\end{array}$ \\
\hline _Cut 4 & $\begin{array}{c}-4.157 * * \\
(0.266)\end{array}$ & $\begin{array}{c}-6.036^{* *} \\
(0.290)\end{array}$ & $\begin{array}{c}-4.340^{* *} \\
(0.268)\end{array}$ & $\begin{array}{c}-1.333^{* *} \\
(0.526)\end{array}$ \\
\hline
\end{tabular}


TABLE 2 Continued

\begin{tabular}{lcccc}
\hline & Base Model & $\begin{array}{l}\text { PTA } \\
\text { Instrument }\end{array}$ & $\begin{array}{l}\text { Regime } \\
\text { Indicator }^{\mathrm{a}}\end{array}$ & $\begin{array}{l}\text { Democracies } \\
\text { Only }\end{array}$ \\
\hline Cut 5 & $-3.280^{* *}$ & $-5.159^{* *}$ & $-3.469^{* *}$ & -0.902 \\
Log-likelihood & $(0.265)$ & $(0.289)$ & $(0.268)$ & $(0.522)$ \\
$N$ & $-14,063.16$ & $-13,955.99$ & $-14,160.66$ & $-2,886.09$ \\
Pseudo- $R^{2}$ & 339,910 & 339,910 & 339,910 & 45,565 \\
& 0.14 & 0.15 & 0.14 & 0.09 \\
\hline
\end{tabular}

Notes:

Entries in parentheses are Huber standard errors clustered on the dyad.

$* * p \leq 0.01 ; * p \leq 0.05$. All tests of statistical significance are two-tailed.

${ }^{a}$ Regime Type $_{i}$ and Regime Type R $_{j}$ are dummy variables.

${ }^{\mathrm{b}}$ There are no cases of two democracies that have a former colonial relationship entering an RIA.

${ }^{c}$ Estimate of standard error is bootstrapped since the predicted value of RIA is an instrument.

higher; and for economic unions, it is almost 50-fold higher. When evaluating the highest value of veto players that is observed for both democracies and autocracies, the differences are less pronounced, but democracies continue to display a greater propensity to form RIAs than autocracies. Democracies are about 20 per cent more likely to form PTAs than autocracies, nearly 25 per cent more likely to form FTAs and customs unions, almost 30 per cent more likely to form common markets, and roughly 40 per cent more likely to form economic unions. These findings accord with our argument that democracies generally are more likely than autocracies to form RIAs, as well as with past work on this topic (Mansfield et al., 2002).

As we mentioned earlier, it is not clear what effect veto players should have in autocracies. Our results indicate that autocratic country-pairs become increasingly likely to enter an RIA as the number of veto players rises. Focusing on the range of veto players that is observed for autocracies, a change from the 10th percentile to the 90th percentile produces a roughly five-fold to six-fold increase in the likelihood of forming an integration arrangement. This effect is much smaller than we found for democracies. Moreover, unlike democracies, the size of this effect does not depend on the proposed level of integration.

Why might autocracies marked by more veto players display a greater propensity for entering RIAs? One possibility is that autocrats use the gains from regional integration as a way to buy off veto players and ensure their loyalty to the regime. Indeed, some studies have argued that autocracies attempt to join regional economic organisations to lock in rules, such as respect for property rights, which guarantee economic advantages for outgoing elites in the event of democratisation (e.g. Pevehouse, 2005). A related possibility is that, as an autocracy's winning 
coalition increases relative to the size of its selectorate, the autocrat faces mounting pressure to provide public goods rather than private ones. Buying off all of the veto players becomes increasingly expensive as their numbers rise, forcing autocrats to behave more like democracies and prompting them to enter RIAs as a means to promote growth and solidify political support.

In addition to regime type and veto players, many control variables in the model influence the proposed level of integration within an RIA. To illustrate the effects of these variables, we focus primarily on the formation of FTAs and common markets, since these types of RIAs occur most frequently in the data. Particularly important is the influence of political-military alliances. The coefficient estimate of Ally $_{i j}$ is positive, statistically significant and fairly sizeable. For example, allies are two and a half times more likely to form FTAs than other states; they are three and a half times more likely to form a common market. This result is consistent with past work suggesting that close political-military relations are an important impetus to more extensive trade relations (Gowa, 1994).

Membership in the GATT/WTO also increases the likelihood of entering an RIA. The estimated coefficient of $G_{A T T}$ ij positive and statistically significant, although its effect seems fairly uniform across different types of integration arrangements. Such membership, for example, increases the probability of forming both an FTA and a common market by about 50 per cent. Further, geographical proximity increases the odds of forming an RIA, especially one that aims to achieve a high level of integration. The estimate of Distance $_{i j}$ is negative and significant; and a change from one standard deviation above its mean value to one standard deviation below its mean increases the probability of forming an FTA by about 150 per cent, a figure that grows to 250 per cent in the case of a common market.

Hegemony also appears to be an important influence on RIAs. The coefficient estimate of this variable is negative and statistically significant. Moreover, a decline in Hegemony from one standard deviation above its mean to one standard deviation below roughly doubles the probability of entering a free trade area or a common market. This suggests that the global distribution of power has important implications for the prospects of regional integration, although it does not seem to have much bearing on the type of integration arrangements that states form. Turning to the remaining political variables in our model, military disputes, former colonial relations and shared borders seem to have little influence on the proposed depth of integration.

Finally, several economic variables influence the proposed level of integration. The estimated coefficients of $G D P_{i}$ and $G D P_{j}$ are negative and statistically significant, suggesting that as states grow economically larger they prefer arrangements that aim to achieve less integration. Since smaller states gain more from greater access to foreign markets than their larger counterparts, it is not surprising that smaller states prefer arrangements that hold out the promise of 
greater integration. It is noteworthy, however, that the substantive effect of these variables is rather small compared to other variables in the model.

The remaining economic variables have a weaker effect than national income. More specifically, the coefficient estimates of $\Delta G D P_{i}$ and $\Delta G D P_{j}$ are positive. But while the former variable is significant, the latter is not, and neither variable has a very sizeable impact on the proposed level of integration within an RIA. Equally, Trade $_{i j}$ has little bearing on the proposed level of integration.

\section{ASSESSING THE ROBUSTNESS OF THE RESULTS}

The preceding results provide strong support for our argument. Democracies are more likely to form RIAs than autocracies. Furthermore, among democracies, reducing the number of veto players increases the odds of forming an integration arrangement. Both the effect of democracy and the effect of veto players within democracies become increasingly pronounced as the proposed level of integration within the arrangement rises. However, it is also important to assess the robustness of these results, particularly with respect to the coding of the dependent variable, the coding of regime type, the estimation technique, and the choice of control variables.

First, we need to ensure that our results do not reflect a selection bias that could arise if the same factors that lead states to enter any type of RIA also affect the type of RIA that they form. To address this issue, we generate the predicted probability of each dyad establishing an RIA in each year, based on a statistical model developed by Mansfield et al. (2002). Including this variable, however, has no bearing on our results. As shown in the second column of Table 2, the coefficient estimate of this variable is negative and statistically significant, reflecting the fact that there are more PTAs and FTAs than CUs and economic unions in our sample. Nonetheless, including this variable has no bearing on the sign, size or significance of our key variables.

Second, many social scientists consider regime type to be a categorical rather than a continuous variable. As such, they distinguish between democracies and other regimes, based on some threshold value (often a score of 17 or higher) of Jaggers and Gurr's (1995) 21-point index, rather than analysing the index itself. Following these studies, we code democracies as countries with a regime type score of 17 or higher. ${ }^{21}$ If a country is democratic, Regime Type is set equal to 1 ; otherwise it is set equal to 0 . We then recalculate Veto Players ${ }_{i} \times$ Regime Type $_{i}$ and Veto Players $_{j} \times$ Regime Type $_{j}$ based on this dichotomous measure of democracy.

${ }^{21}$ This is one of the traditional cut-offs for defining democracies in much of the political science literature. We relax this threshold in a series of tests and find that doing so only strengthens our results. 
The estimates of this new specification are reported in the third column of Table 2. Like before, the estimated coefficients of Veto Players ${ }_{i}$, Veto Players ${ }_{j}$, Regime Type $_{i}$ and Regime Type Re positive; and the estimates of Veto Players $_{i}$ $\times$ Regime Type $_{i}$ and Veto Players ${ }_{j} \times$ Regime Type $_{j}$ are negative. Each estimate except Veto Players ${ }_{j}$ is statistically significant. In addition, the coefficient estimates of the control variables do not depend on whether we treat regime type as a continuous or a dichotomous variable. These results, then, are quite similar to our initial findings, although (in light of the insignificant estimate of Veto Players ${ }_{j}$ ) they provide somewhat weaker evidence that veto players influence the extent of proposed integration in non-democratic regimes.

To further address this issue, we consider only those dyads composed of two democracies (i.e. two countries with a regime type score of 17 or higher in a given year) and then estimate the model after dropping Regime Type R $_{\text {, Regime }}$ Type $_{j}$, Veto Players ${ }_{i} \times$ Regime Type $_{i}$ and Veto Players ${ }_{j} \times$ Regime Type $_{j}$. As shown in the final column of Table 2, the coefficient estimates of Veto Players ${ }_{i}$ and

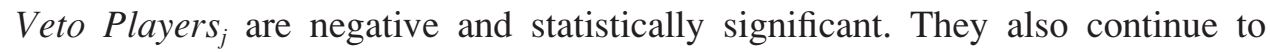
indicate that veto players have a substantively large effect on the type of RIA that democracies elect to enter.

Third, we have analysed all dyads for which data on the variables in equation (1) are available. However, it is useful to assess whether our results hold after excluding cases where the flow of bilateral trade is reported as zero in a given year. We have relied on data on bilateral trade flows compiled by Gleditsch (2002), much of which is taken from the International Monetary Fund's (IMF's) Direction of Trade Statistics. That dataset does not distinguish between situations in which no trade was conducted by a pair of countries and cases where the pair did not report any trade to the IMF. As such, it is not clear how to interpret situations in which the flow of trade is zero in the dataset. Moreover, those dyads that actually did not conduct any trade in a given year could be considered unimportant to the international trading system and particularly unlikely to form any type of RIA. In the first column of Table 3, we report the estimates of our model after excluding dyad years in which the value of bilateral trade is zero. Clearly, omitting these observations has little bearing on our earlier findings.

Fourth, it may be the case that certain RIAs are established because they are politically expedient, but that neither leaders nor societal groups expect the arrangements to have a strong economic impact. If so, veto players might have little effect on the establishment of such RIAs. It is, of course, extremely difficult to systematically measure domestic actors' expectations about the likely effect of a regional arrangement. We can, however, distinguish between arrangements that had a large impact on trade among members and those that had a more modest impact. In the second column of Table 3, we present the results of an ordered probit model that is estimated after removing from our sample those RIAs where 
TABLE 3

Alternative Specifications of the Effects of Veto Players and Regime Type on the Depth of Regional Integration, 1950-2000

\begin{tabular}{|c|c|c|c|c|c|}
\hline & $\begin{array}{l}\text { Exclude Zero } \\
\text { Trade Pairs }\end{array}$ & $\begin{array}{l}\text { Exclude } \\
\text { Dormant RIAs }\end{array}$ & $\begin{array}{l}\text { First RIA } \\
\text { Only }\end{array}$ & $\begin{array}{l}\text { RIA Cases } \\
\text { Only }\end{array}$ & $\begin{array}{l}\text { Three-Category } \\
\text { Dependent } \\
\text { Variable }^{\mathrm{a}}\end{array}$ \\
\hline Veto Points $_{i}$ & $\begin{array}{l}1.184 * * \\
(0.178)\end{array}$ & $\begin{array}{l}0.959 * * \\
(0.010)\end{array}$ & $\begin{array}{l}1.086 * * \\
(0.200)\end{array}$ & $\begin{array}{l}2.177 * * \\
(0.380)\end{array}$ & $\begin{array}{l}1.054 * * \\
(0.164)\end{array}$ \\
\hline Veto Points & $\begin{array}{l}0.970 * * \\
(0.191)\end{array}$ & $\begin{array}{l}0.773^{* *} * \\
(0.174)\end{array}$ & $\begin{array}{l}0.791 * * \\
(0.214)\end{array}$ & $\begin{array}{l}1.724 * * \\
(0.420)\end{array}$ & $\begin{array}{l}0.851 * * \\
(0.173)\end{array}$ \\
\hline Regime Type $_{i}$ & $\begin{array}{l}0.022 * * \\
(0.003)\end{array}$ & $\begin{array}{l}0.028 * * \\
(0.002)\end{array}$ & $\begin{array}{l}0.030 * * \\
(0.002)\end{array}$ & $\begin{array}{l}0.026 * * \\
(0.006)\end{array}$ & $\begin{array}{l}0.028 * * \\
(0.002)\end{array}$ \\
\hline Regime Type $_{j}$ & $\begin{array}{l}0.019 * * \\
(0.003)\end{array}$ & $\begin{array}{l}0.023 * * \\
(0.002)\end{array}$ & $\begin{array}{l}0.025^{* *} \\
(0.002)\end{array}$ & $\begin{array}{l}0.031 * * \\
(0.006)\end{array}$ & $\begin{array}{l}0.024 * * \\
(0.002)\end{array}$ \\
\hline $\begin{array}{c}\text { Regime Type }_{i} \times \\
\text { Veto Points }\end{array}$ & $\begin{array}{l}-0.099 * * \\
(0.011)\end{array}$ & $\begin{array}{l}-0.095 * * \\
(0.010)\end{array}$ & $\begin{array}{l}-0.107 * * \\
(0.011)\end{array}$ & $\begin{array}{l}-0.144 * * \\
(0.026)\end{array}$ & $\begin{array}{l}-0.102 * * \\
(0.009)\end{array}$ \\
\hline $\begin{array}{c}\text { Regime }^{\text {Rype }}{ }_{j} \times \\
\text { Veto Points } \\
j\end{array}$ & $\begin{array}{c}-0.087 * * \\
(0.011)\end{array}$ & $\begin{array}{c}-0.085^{* *} \\
(0.010)\end{array}$ & $\begin{array}{l}-0.092 * * \\
(0.012)\end{array}$ & $\begin{array}{l}-0.123 * * \\
(0.027)\end{array}$ & $\begin{array}{c}-0.092 * * \\
(0.010)\end{array}$ \\
\hline Trade $_{i j}$ & $\begin{array}{l}-0.022 * * \\
(0.006)\end{array}$ & $\begin{array}{c}-0.001 \\
(0.003)\end{array}$ & $\begin{array}{c}-0.003 \\
(0.003)\end{array}$ & $\begin{array}{c}-0.005 \\
(0.008)\end{array}$ & $\begin{array}{c}-0.001 \\
(0.003)\end{array}$ \\
\hline$G D P_{i}$ & $\begin{array}{c}-0.036 * * \\
(0.009)\end{array}$ & $\begin{array}{l}-0.064 * * \\
(0.007)\end{array}$ & $\begin{array}{l}-0.078 * * \\
(0.008)\end{array}$ & $\begin{array}{c}-0.062 * * \\
(0.020)\end{array}$ & $\begin{array}{c}-0.068 * * \\
(0.006)\end{array}$ \\
\hline$G D P_{j}$ & $\begin{array}{l}-0.038 * * \\
(0.009)\end{array}$ & $\begin{array}{l}-0.057 * * \\
(0.006)\end{array}$ & $\begin{array}{l}-0.072 * * \\
(0.007)\end{array}$ & $\begin{array}{l}-0.065^{* *} * \\
(0.022)\end{array}$ & $\begin{array}{c}-0.060 * * \\
(0.006)\end{array}$ \\
\hline$\Delta G D P_{i}$ & $\begin{array}{c}4.10 \times 10^{-10} \\
\left(4.20 \times 10^{-10}\right)\end{array}$ & $\begin{array}{c}7.48 \times 10^{-10} \\
\left(3.96 \times 10^{-10}\right)\end{array}$ & $\begin{array}{c}7.72 \times 10^{-10} \\
\left(4.74 \times 10^{-10}\right)\end{array}$ & $\begin{array}{c}-3.56 \times 10^{-9} * * \\
\left(1.14 \times 10^{-9}\right)\end{array}$ & $\begin{array}{c}8.96 \times 10^{-10} \\
\left(4.00 \times 10^{-10}\right)\end{array}$ \\
\hline$\Delta G D P_{j}$ & $\begin{array}{c}4.54 \times 10^{-10} \\
\left(3.75 \times 10^{-10}\right)\end{array}$ & $\begin{array}{c}5.34 \times 10^{-9} \\
\left(3.76 \times 10^{-9}\right)\end{array}$ & $\begin{array}{r}8.36 \times 10^{-10 *} \\
\left(4.24 \times 10^{-10}\right)\end{array}$ & $\begin{array}{c}-6.07 \times 10^{-9 * *} \\
\left(1.76 \times 10^{-9}\right)\end{array}$ & $\begin{array}{c}7.42 \times 10^{-10} \\
\left(3.67 \times 10^{-10}\right)\end{array}$ \\
\hline Dispute $_{i j}$ & $\begin{array}{c}-0.107 \\
(0.111)\end{array}$ & $\begin{array}{l}-0.149 \\
(0.105)\end{array}$ & $\begin{array}{r}-0.350 * \\
(0.139)\end{array}$ & $\begin{array}{l}-0.145 \\
(0.211)\end{array}$ & $\begin{array}{r}-0.169 \\
(0.105)\end{array}$ \\
\hline Ally $y_{i j}$ & $\begin{array}{l}0.478 * * \\
(0.028)\end{array}$ & $\begin{array}{l}0.539 * * \\
(0.025)\end{array}$ & $\begin{array}{l}0.647 * * \\
(0.029)\end{array}$ & $\begin{array}{c}-0.036 \\
(0.071)\end{array}$ & $\begin{array}{l}0.505 * * \\
(0.026)\end{array}$ \\
\hline Former Colony $y_{i j}$ & $\begin{array}{c}-0.301 \\
(0.217)\end{array}$ & $\begin{array}{c}-0.441 \\
(0.303)\end{array}$ & $\begin{array}{c}-0.121 \\
(0.332)\end{array}$ & ${ }^{\mathrm{b}}$ & $\begin{array}{c}-0.289 \\
(0.221)\end{array}$ \\
\hline Contiguity $_{i j}$ & $\begin{array}{c}-0.010 \\
(0.041)\end{array}$ & $\begin{array}{c}-0.101^{*} \\
(0.041)\end{array}$ & $\begin{array}{c}-0.071 \\
(0.053)\end{array}$ & $\begin{array}{c}0.086 \\
(0.084)\end{array}$ & $\begin{array}{r}-0.071 \\
(0.039)\end{array}$ \\
\hline Distance $_{i j}$ & $\begin{array}{c}-0.353 * * \\
(0.018)\end{array}$ & $\begin{array}{c}-0.396 * * \\
(0.014)\end{array}$ & $\begin{array}{c}-0.450 * * \\
(0.016)\end{array}$ & $\begin{array}{c}0.048 \\
(0.043)\end{array}$ & $\begin{array}{c}-0.385 * * \\
(0.015)\end{array}$ \\
\hline Hegemony & $\begin{array}{l}-7.220 * * \\
(0.685)\end{array}$ & $\begin{array}{c}-10.562 * * \\
(0.615)\end{array}$ & $\begin{array}{c}-11.519 * * \\
(0.690)\end{array}$ & $\begin{array}{c}-6.045^{* *} \\
(1.965)\end{array}$ & $\begin{array}{l}-9.681 * * \\
(0.610)\end{array}$ \\
\hline$G A T T_{i j}$ & $\begin{array}{l}0.184 * * \\
(0.023)\end{array}$ & $\begin{array}{c}0.166^{* *} \\
(0.018)\end{array}$ & $\begin{array}{l}0.226 * * \\
(0.022)\end{array}$ & $\begin{array}{l}0.436 * * \\
(0.044)\end{array}$ & $\begin{array}{l}0.159^{* *} \\
(0.019)\end{array}$ \\
\hline Instrument[RIA] & - & - & - & $\begin{array}{l}0.407 \\
(0.910)^{\mathrm{c}}\end{array}$ & - \\
\hline C Cut 1 & $\begin{array}{l}-2.289 * * \\
(0.329)\end{array}$ & $\begin{array}{c}-4.528 * * \\
(0.262)\end{array}$ & $\begin{array}{c}-5.587 * * \\
(0.305)\end{array}$ & $\begin{array}{l}-4.116^{* *} \\
(0.814)\end{array}$ & $\begin{array}{c}-4.371 * * \\
(0.263)\end{array}$ \\
\hline _Cut 2 & $\begin{array}{l}-2.275^{* * *} \\
(0.329)\end{array}$ & $\begin{array}{l}-4.502 * * \\
(0.262)\end{array}$ & $\begin{array}{l}-5.550^{* *} \\
(0.305)\end{array}$ & $\begin{array}{l}-2.830 * * \\
(0.814)\end{array}$ & $\begin{array}{c}-4.345^{* *} \\
(0.263)\end{array}$ \\
\hline _Cut 3 & $\begin{array}{l}-2.560 * * \\
(0.329)\end{array}$ & $\begin{array}{c}-4.338 * * \\
(0.262)\end{array}$ & $\begin{array}{c}-5.347 * * \\
(0.306)\end{array}$ & $\begin{array}{l}-2.485 * * \\
(0.812)\end{array}$ & $\begin{array}{c}-4.188 * * \\
(0.263)\end{array}$ \\
\hline _Cut 4 & $\begin{array}{l}-2.472 * * \\
(0.329)\end{array}$ & $\begin{array}{l}-4.251 * * \\
(0.262)\end{array}$ & $\begin{array}{l}-5.247 * * \\
(0.305)\end{array}$ & $\begin{array}{c}-0.562 * * \\
(0.820)\end{array}$ & - \\
\hline$\_$Cut 5 & $\begin{array}{l}-1.699 * * \\
(0.329)\end{array}$ & $\begin{array}{l}-3.350 * * \\
(0.262)\end{array}$ & - & - & - \\
\hline
\end{tabular}


TABLE 3 Continued

\begin{tabular}{lcllll}
\hline & $\begin{array}{l}\text { Exclude Zero } \\
\text { Trade Pairs }\end{array}$ & $\begin{array}{l}\text { Exclude } \\
\text { Dormant RIAs }\end{array}$ & $\begin{array}{l}\text { First RIA } \\
\text { Only }\end{array}$ & $\begin{array}{l}\text { RIA Cases } \\
\text { Only }\end{array}$ & $\begin{array}{l}\text { Three-Category } \\
\text { Dependent } \\
\text { Variable }^{\mathrm{a}}\end{array}$ \\
\hline Log-likelihood & $-9,827.13$ & $-13,208.11$ & $-9,577.42$ & $-2,726.05$ & $-13,040.31$ \\
$N$ & 211,413 & 329,500 & 302,324 & 2,252 & 339,910 \\
Pseudo- $R^{2}$ & 0.13 & 0.15 & 0.15 & 0.05 & 0.15 \\
\hline
\end{tabular}

Notes:

Parameters are estimated using ordered probit regression. Entries in parentheses are Huber standard errors clustered on the dyad.

$* * p \leq 0.01 ; * p \leq 0.05$. All tests of statistical significance are two-tailed.

${ }^{a}$ Dependent variable is collapsed to three categories: (1) PTA, (2) FTA and (3) customs union/common market/economic union.

${ }^{\mathrm{b}}$ Former Colony perfectly predicts RIAs in this estimation and so is excluded.

${ }^{\mathrm{c}}$ Estimate of standard error is bootstrapped since the predicted value of PTA is an instrument.

the average change in bilateral trade between members during the previous three years was not positive. ${ }^{22}$ Again, our results are quite robust with respect to this change in the sample.

Fifth, we analyse whether the results are sensitive to various modelling decisions. As noted earlier, the observed value of our dependent variable is non-zero only in those years $(t+1)$ when states $i$ and $j$ enter an RIA. We do not remove observations after the pair signed an agreement because various dyads established more than one RIA during the period we analyse. In many of these cases, they formed a second RIA without terminating the first. Nonetheless, it is important to assess the implications of this modelling strategy. For any pair of states that form an RIA, we therefore eliminate every observation after the arrangement is established and then re-estimate the model. As shown in the third column of Table 3, the influence of regime type and veto players does not depend on whether we include or exclude these observations.

Another modelling issue that merits attention stems from the fact that most of the variation in our dataset is cross-sectional. Although various dyads form more than one RIA, most form none at all and those that do form one generally do not establish another. To ensure that treating our dataset as a time-series crosssection does not influence our results, we select only those observations where a pair of states formed an arrangement. We then code the dependent variable as zero if the pair formed a PTA, one if they created an FTA, two if they established

\footnotetext{
${ }^{22}$ We use a three-year period since exogenous changes rather than non-compliance could lead to declines in trade in the RIA over shorter periods.
} 
a customs union, three if they entered a common market, and four if they joined an economic union. We also include the predicted probability of forming an RIA to account for any selection bias generated by sampling on cases where states entered such an arrangement. The results in the fourth column of Table 3 are much the same as our earlier results. Consequently, it makes little difference whether we treat the data as a time-series cross-section.

Sixth, we mentioned earlier that customs unions and economic unions occur much less frequently than PTAs, FTAs and common markets. To ensure that our results are not unduly influenced by this characteristic of the data, we collapse our dependent variable into three categories: (1) preferential trade agreements, (2) free trade agreements and (3) customs unions/common markets/economic unions. We again estimate our model using an ordered probit specification. The results, presented in the final column of Table 3, are remarkably consistent with our previous estimates. The signs, sizes and significance levels of every variable except $\Delta G D P_{j}$ - which is now statistically significant - are virtually identical to those based on our five-category classification of RIAs.

Seventh, our dependent variable is an ordered, nominal measure of the extent of proposed integration. This variable is quite useful and appropriate in light of our purpose here, but analysing it and estimating our model using an ordered probit specification places certain restrictions on our parameter estimates namely, imposing the assumption that each independent variable has a monotonic effect on the dependent variable. It is therefore useful to estimate the model using a multinomial logit treatment, which allows us to eliminate this restriction on the parameter estimates and also to relax the assumption that the different types of RIAs are ordered.

To conduct this analysis, we again separate RIAs into three categories: PTAs, FTAs and customs unions/common markets/economic unions. ${ }^{23}$ The results are presented in Table 4. The first column shows the estimates for PTA formation. Clearly, regime type and veto players do not exert a strong influence on the decision to enter such an arrangement. Given that these RIAs are quite 'shallow' - often covering very few goods and services - this result is not entirely surprising. Among parties to a PTA, relatively few domestic interests will have to bear whatever adjustment costs are created by the arrangement.

Regime type and veto players, however, do exert a large and strong effect on FTA formation, and an even larger and stronger influence on the establishment of CUs/common markets/economic unions. In the second and third columns of Table 4, the estimated coefficients of Veto Players ${ }_{i}$, Veto Players ${ }_{j}$, Regime Type ${ }_{i}$

${ }^{23}$ We use the three-outcome dependent variable because of the shortage of cases in some of the five-category outcomes (specifically, customs unions and economic unions). We also remove Former Colony ${ }_{i j}$ since there is nearly no variation in this variable when analysing the highest proposed level of integration. 
TABLE 4

Multinomial Logit Estimates of the Effects of Veto Players and Regime Type on the Depth of Regional Integration, 1950-2000

\begin{tabular}{|c|c|c|c|}
\hline & $P T A$ & FTA & $C U / C M / E U$ \\
\hline Veto Players ${ }_{i}$ & $\begin{array}{c}-7.821^{*} \\
(3.664)\end{array}$ & $\begin{array}{l}1.759 * * \\
(0.551)\end{array}$ & $\begin{array}{l}3.449 * * \\
(0.529)\end{array}$ \\
\hline Veto Players & $\begin{array}{c}-3.732 \\
(2.503)\end{array}$ & $\begin{array}{l}1.881 * * \\
(0.536)\end{array}$ & $\begin{array}{l}2.525 * * \\
(0.584)\end{array}$ \\
\hline Regime Type $_{i}$ & $\begin{array}{c}0.033 \\
(0.019)\end{array}$ & $\begin{array}{l}0.051 * * \\
(0.010)\end{array}$ & $\begin{array}{l}0.080 * * \\
(0.007)\end{array}$ \\
\hline Regime Type $_{j}$ & $\begin{array}{c}0.015 \\
(0.022)\end{array}$ & $\begin{array}{l}0.037 * * \\
(0.010)\end{array}$ & $\begin{array}{l}0.072 * * \\
(0.006)\end{array}$ \\
\hline $\begin{array}{r}\text { Regime Type }_{i} \times \\
\text { Veto Players }_{4}\end{array}$ & $\begin{array}{c}0.255 \\
(0.185)\end{array}$ & $\begin{array}{c}-0.141^{* *} \\
(0.036)\end{array}$ & $\begin{array}{c}-0.330 * * \\
(0.031)\end{array}$ \\
\hline $\begin{array}{r}{\text { Regime } \text { Type }_{j} \times} \times \\
\text { Veto Players }\end{array}$ & $\begin{array}{c}0.078 \\
(0.131)\end{array}$ & $\begin{array}{c}-0.131 * * \\
(0.035)\end{array}$ & $\begin{array}{c}-0.297 * * \\
(0.033)\end{array}$ \\
\hline Trade $_{i j}$ & $\begin{array}{c}-0.008 \\
(0.035)\end{array}$ & $\begin{array}{c}0.004 \\
(0.013)\end{array}$ & $\begin{array}{c}-0.005 \\
(0.009)\end{array}$ \\
\hline$G D P_{i}$ & $\begin{array}{r}-0.143^{*} \\
(0.070)\end{array}$ & $\begin{array}{c}-0.002 \\
(0.031)\end{array}$ & $\begin{array}{c}-0.235 * * \\
(0.022)\end{array}$ \\
\hline$G D P_{j}$ & $\begin{array}{c}0.010 \\
(0.071)\end{array}$ & $\begin{array}{c}-0.036 \\
(0.030)\end{array}$ & $\begin{array}{c}-0.189 * * \\
(0.021)\end{array}$ \\
\hline$\Delta G D P_{i}$ & $\begin{array}{r}-5.56 \times 10^{-9} \\
\left(5.73 \times 10^{-9}\right)\end{array}$ & $\begin{array}{c}2.09 \times 10^{-9} \\
\left(1.11 \times 10^{-9}\right)\end{array}$ & $\begin{array}{c}-5.39 \times 10^{-9} * * \\
\left(2.04 \times 10^{-9}\right)\end{array}$ \\
\hline$\Delta G D P_{j}$ & $\begin{array}{r}-1.31 \times 10^{-8} \\
\left(7.76 \times 10^{-9}\right)\end{array}$ & $\begin{array}{l}2.83 \times 10^{-9 * *} \\
\left(9.45 \times 10^{-10}\right)\end{array}$ & $\begin{array}{c}-5.05 \times 10^{-9} * * \\
\left(1.41 \times 10^{-9}\right)\end{array}$ \\
\hline Dispute $_{i j}$ & $\begin{array}{l}-1.267 \\
(1.050)\end{array}$ & $\begin{array}{c}0.072 \\
(0.323)\end{array}$ & $\begin{array}{l}-0.615 \\
(0.324)\end{array}$ \\
\hline Ally $_{i j}$ & $\begin{array}{l}2.022 * * \\
(0.304)\end{array}$ & $\begin{array}{l}1.172 * * \\
(0.115)\end{array}$ & $\begin{array}{l}1.106 * * \\
(0.093)\end{array}$ \\
\hline Contiguity $_{i j}$ & $\begin{array}{c}-0.383^{* * *} \\
(0.101)\end{array}$ & $\begin{array}{c}-0.350^{*} \\
(0.168)\end{array}$ & $\begin{array}{c}-0.269 * \\
(0.134)\end{array}$ \\
\hline Distance $_{i j}$ & $\begin{array}{c}-0.621 * * \\
(0.151)\end{array}$ & $\begin{array}{c}-0.900 * * \\
(0.057)\end{array}$ & $\begin{array}{c}-0.889 * * \\
(0.056)\end{array}$ \\
\hline Hegemony & $\begin{array}{c}-15.943 * * \\
(5.700)\end{array}$ & $\begin{array}{c}-29.942 * * \\
(3.343)\end{array}$ & $\begin{array}{c}-22.008 * * \\
(2.000)\end{array}$ \\
\hline$G A T T_{i j}$ & $\begin{array}{c}-0.867 * * \\
(0.279)\end{array}$ & $\begin{array}{c}-0.189 * \\
(0.090)\end{array}$ & $\begin{array}{l}0.634 * * \\
(0.062)\end{array}$ \\
\hline Constant & $\begin{array}{c}2.628 \\
(2.302)\end{array}$ & $\begin{array}{l}7.075^{* *} \\
(1.254)\end{array}$ & $\begin{array}{l}12.224 * * \\
(0.891)\end{array}$ \\
\hline $\begin{array}{l}\text { Log-likelihood } \\
N \\
\text { Pseudo- } R^{2}\end{array}$ & & $\begin{array}{l}-12,962.38 \\
339,910 \\
0.16\end{array}$ & \\
\hline
\end{tabular}

Notes:

Entries in parentheses are Huber standard errors clustered on the dyad.

$* * p \leq 0.01 ; * p \leq 0.05$. All tests of statistical significance are two-tailed. 
and Regime Type $e_{i}$ are positive; the estimates of Veto Players ${ }_{i} \times$ Regime Type $_{i}$ and Veto Players $_{j} \times$ Regime Type $_{j}$ are negative; and all of these estimates are statistically significant. Moreover, the absolute value of each coefficient estimate associated with CUs/common markets/economic unions is much larger than the corresponding estimate for FTAs. These results are quite consistent with our earlier findings based on the ordered probit specification. So too are the substantive effects of regime type and veto players. The predicted probability of two democracies forming an FTA rises two-and-a-half-fold as the number of veto players decreases from the 90th percentile to the 10th percentile found in the data. Such a change yields an almost 20-fold rise in the likelihood of forming a CU/common market/ economic union. Thus, the effects of veto players in democracies continue to be much more pronounced as the proposed integration within an RIA becomes more extensive. Equally, these results continue to show that pairs of democracies are much more likely than pairs of autocracies to join integration arrangements.

Eighth, we include a series of variables that are omitted from equation (1) and that might affect our earlier results; we also make some modifications to our research design to ensure that these changes do not affect our results. We add country-specific fixed effects to account for any unobserved heterogeneity in the data. We re-specify our measures of regime type and veto players using an additive form. More specifically, we replace Veto Players, , Veto Players $_{j}$, Regime Type $_{i}$, Regime Type , Veto Players $_{i} \times$ Regime Type $_{i}$ and Veto Players ${ }_{j} \times$ Regime $T_{y p e_{j}}$ with the sum of state $i$ 's and state $j$ 's scores for both Regime Type and Veto Players, as well as the interaction between these variables. We include a variable indicating whether either state in a given dyad is imposing economic sanctions on the other state, since this might reduce the willingness of the target state to enter an arrangement that aims to achieve a high level of integration. ${ }^{24} \mathrm{We}$ introduce a measure of the similarity of states' political preferences, since dyads that have more similar preferences might find it easier to conclude agreements that propose extensive integration. ${ }^{25} \mathrm{We}$ include a measure of the number of intergovernmental organisations that states $i$ and $j$ are members of, since this might be indicative of their willingness to engage in more extensive and cooperative trade agreements. ${ }^{26}$

Further, we analyse whether the European Community (EC) and the European Union (EU) have a strong influence on our findings. Participants in these institutions have been especially active in forming RIAs and we want to ensure that they are not driving our results. To this end we include a variable indicating

\footnotetext{
${ }^{24}$ Data are taken from Hufbauer et al. (1990; Institute for International Economics http:// www.iie.org). All sanctions episodes (bilateral and multilateral) are included.

${ }^{25}$ Data for this variable are taken from Gartzke (1998). Some studies of international relations have recently begun to use a different measure of preference similarity, referred to as $S$ (Signorino and Ritter, 1999). Our results do not depend on which measure is used.

${ }^{26}$ Data for this variable are taken from Pevehouse et al. (2004).
} 
whether both states in the country-pair are members of the EC/EU in year $t$. We also estimate the model after excluding these pairs altogether.

Finally, because we use time-series cross-section data, there is a threat of temporal dependence in our model. We therefore follow Beck et al. (1998) in creating a variable counting the number of years between joining any type of regional agreement. We then use this variable as the base of a cubic spline function with three knots, and add this set of variables to our original model. ${ }^{27}$

None of these supplementary tests have any bearing on our results. In every case, the coefficient estimates of Veto Players ${ }_{i}$, Veto Players , Regime Type $_{i}$ and Regime Type $_{j}$ are positive; the estimates of Veto Players ${ }_{i} \times$ Regime Type $_{i}$ and Veto Players ${ }_{j} \times$ Regime Type $_{j}$ are negative; and all of these estimates are statistically significant. ${ }^{28}$ Equally, the size of these estimates is very similar to those reported earlier. Thus, the results are quite robust with respect to various re-specifications of our model.

\section{CONCLUSIONS}

Over the past decade, mounting interest has been expressed in the political economy of regionalism. Some studies have addressed the domestic politics underlying the formation of RIAs. Virtually no research, however, has analysed the factors influencing the type of integration arrangement that is chosen.

In this paper, we have argued that leaders in democracies have a strong incentive to join regional integration agreements. Such agreements help spur economic growth, which is likely to benefit the median voter in a large selectorate, while also providing information to the electorate about the competence of the leadership. Furthermore, within democracies, a rise in the number of veto players reduces the prospect of a state entering an RIA, an effect that grows larger as the proposed level of integration in an arrangement grows deeper. The increasing costs of adjustment stemming from deeper policy coordination will bring pressure on democratically-elected governments by the segments of society that expect to bear the brunt of these costs.

Our statistical results support this argument. As the number of veto players increases, as preferences between those institutions diverge, and as preferences within the institutions become more heterogeneous, the likelihood of democracies entering arrangements that propose deeper regional integration declines quite

\footnotetext{
${ }^{27}$ We also added three spline functions to our multinomial logit models - one for each possible outcome variable. Their inclusion did nothing to change the coefficient estimates of our key variables. ${ }^{28}$ Where the sums of Veto Players $_{i}$ and Veto Players ${ }_{j}$ and of Regime Type ${ }_{i}$ and Regime Type Re $_{j}$ are analysed, the coefficient estimates of these variables are positive, the estimate of the interaction between them is negative, and all three estimates are statistically significant.
} 
dramatically. Our results are robust to re-specifications of our dependent variable and several key independent variables, as well as to our choice of estimation technique.

Thus, while democracies have a particular interest in regional integration arrangements, the type of arrangements they enter depends centrally on institutions and preferences within these countries. A hallmark of most democracies is the checks and balances that exist among different branches of government. This feature has many important benefits. Nonetheless, the presence of a large number of checks and balances augurs poorly for promoting international economic cooperation and fostering deeper economic integration.

\section{REFERENCES}

Baier, S. L. and J. H. Bergstrand (2004), 'Economic Determinants of Free Trade Agreements', Journal of International Economics, 64, 1, 29-63.

Baldwin, R. E. and A. J. Venables (1995), 'Regional Economic Integration', in G. M. Grossman and K. Rogoff (eds.), Handbook of International Economics, Vol. 3 (Amsterdam: Elsevier).

Beck, N., J. N. Katz and R. Tucker (1998), 'Taking Time Seriously: Time-Series-Cross-Section Analysis with a Binary Dependent Variable', American Journal of Political Science, 42, 4, 1260-88.

Beck, T., G. Clarke, A. Groff, P. Keeler and P. Walsh (2001), 'New Tools and New Tests in Comparative Political Economy: The Database of Political Institutions', World Bank Economic Review, 15, 1, 165-76.

Bhagwati, J. (1993), 'Regionalism and Multilateralism: An Overview', in J. de Melo and A. Panagariya (eds.), New Dimensions in Regional Integration (New York: Cambridge University Press).

Bhagwati, J. N. and A. Panagariya (eds.) (1996), The Economics of Preferential Trade Agreements (Washington, DC: AEI Press).

Bueno de Mesquita, B., A. Smith, R. Siverson and J. Morrow (2003), The Logic of Political Survival (Cambridge, MA: MIT Press).

Cassing, J. H. and A. L. Hillman (1986), 'Shifting Comparative Advantage and Senescent Industry Collapse', American Economic Review, 76, 3, 516-23.

de Melo, J. and A. Panagariya (eds.) (1993), New Dimensions in Regional Integration (New York: Cambridge University Press).

Fernández, R. and D. Rodrik (1991), 'Resistance to Reform: Status Quo Bias in the Presence of Individual-Specific Uncertainty', American Economic Review, 81, 5, 1146-55.

Frankel, J. and D. Romer (1999), 'Does Trade Cause Growth?', American Economic Review, 89, 3, 379-99.

Freund, C. (2000), 'Multilateralism and the Endogenous Formation of Preferential Trade Agreements', Journal of International Economics, 52, 2, 359-76.

Frye, T. and E. D. Mansfield (2003), 'Fragmenting Protection: The Political Economy of Trade Policy in the Post-Communist World', British Journal of Political Science, 33, 4, 635-57.

Gartzke, E. (1998), 'Kant We All Just Get Along? Opportunity, Willingness, and the Origins of the Democratic Peace', American Journal of Political Science, 42, 1, 1-27.

Ghosn, F. and G. Palmer (2003), 'Codebook for the Militarized Interstate Dispute Data, Version 3.0'. Online: http://cow2.la.psu.edu.

Gibler, D. M. and M. Sarkees (2003), 'Measuring Alliances: The Correlates of War Formal Interstate Alliance Data Set, 1816-2000'. Online: http://cow2.la.psu.edu.

Gilligan, M. J. (1997), Empowering Exporters: Reciprocity, Delegation, and Collective Action in American Trade Policy (Ann Arbor, MI: University of Michigan Press). 
Gleditsch, K. (2002), 'Expanded Trade and GDP Data', Journal of Conflict Resolution, 46, 5, 712-24.

Gleditsch, K. (2004), 'Modified Polity 4 Data'. Online: http://weber.ucsd.edu/ kgledits/Polity.html. Gowa, J. (1994), Allies, Adversaries, and International Trade (Princeton, NJ: Princeton University Press).

Grossman, G. and E. Helpman (1995), 'The Politics of Free Trade Agreements', American Economic Review, 85, 4, 667-90.

Hawkins, D., D. Lake, D. Nelson and M. Tierney (eds.) (2006), Delegation Under Anarchy: States, International Organizations and Principal Agent Theory (Cambridge: Cambridge University Press).

Henisz, W. J. (2000), 'The Institutional Environment for Economic Growth', Economics and Politics, 12, 1, 1-31.

Henisz, W. J. (2002), 'The Institutional Environment for Infrastructure Investment', Industrial and Corporate Change, 11, 2, 355-89.

Henisz, W. J. and E. D. Mansfield (2006), 'Votes and Vetoes: The Political Determinants of Commercial Openness', International Studies Quarterly, 50, 1, 189-212.

Hillman, A. L. (1982), 'Declining Industries and Political-Support Protectionist Motives', American Economic Review, 72, 5, 1180-87.

Hufbauer, G. (1989), The Free Trade Debate: Reports of the Twentieth Century Fund Task Force on the Future of American Trade Policy (New York: Priority Press).

Hufbauer, G. C., J. J. Schott and K. A. Elliot (1990), Economic Sanctions Reconsidered, 2nd edn (Washington, DC: Institute for International Economics).

Jaggers, K. and T. R. Gurr (1995), 'Tracking Democracy's Third Wave with the Polity III Data', Journal of Peace Research, 32, 6, 469-82.

Jones, D., S. Bremer and J. D. Singer (1996), 'Militarized Interstate Disputes, 1816-1992: Rationale, Coding Rules, and Empirical Patterns', Conflict Management and Peace Science, 15, 2, 163-213.

Krishna, P., A. Panagariya and J. Bhagwati (eds.) (1999), Trading Blocs: Alternative Approaches to Analyzing Preferential Trade Agreements (Cambridge, MA: MIT Press).

Krueger, A. O. (1997), 'Free Trade Agreements versus Customs Unions', Journal of Development Economics, 54, 1, 169-87.

Krugman, P. (1993), 'Regionalism versus Multilateralism: Analytical Notes', in J. de Melo and A. Panagariya (eds.), New Dimensions in Regional Integration (New York: Cambridge University Press).

Kurian, G. T. (1992), Encyclopedia of the Third Word, 4th edn, Vols 1-3 (New York: Facts on File).

Lipsey, R. (1960), 'The Theory of Customs Unions: A General Survey', The Economic Journal, 70, 496-513.

Lloyd, P. J. and D. MacLaren (2004), 'Gains and Losses from Regional Trading Agreements: A Survey', Economic Record, 80, 251, 445-68.

Long, V. N. and N. Vousden (1991), 'Protectionist Responses and Declining Industries', Journal of International Economics, 30, 1, 87-103.

Mansfield, E. D. (1998), 'The Proliferation of Preferential Trading Arrangements', Journal of Conflict Resolution, 42, 5, 523-43.

Mansfield, E. D. and J. C. Pevehouse (2000), 'Trade Blocs, Trade Flows, and International Conflict', International Organization, 54, 4, 775-808.

Mansfield, E. D. and E. Reinhardt (2003), 'Multilateral Determinants of Regionalism: The Effects of GATT/WTO on the Formation of Preferential Trading Arrangements', International Organization, 57, 4, 829-62.

Mansfield, E. D., H. V. Milner and J. C. Pevehouse (2007), 'Vetoing Cooperation: The Impact of Veto Players on Preferential Trading Arrangements', British Journal of Political Science, 37, 3, 403-32.

Mansfield, E. D., H. V. Milner and B. P. Rosendorff (2002), 'Why Democracies Cooperate More: Electoral Control and International Trade Agreements', International Organization, 56, 3, 477514.

Marshall, M. (2004), Polity 4 Data Set Codebook. http://www.cidcm.umd.edu/inscr/Polity/index.htm.

Mattli, W. (1999), The Logic of Regional Integration: Europe and Beyond (Cambridge: Cambridge University Press). 
Mayer, W. (1984), 'Endogenous Tariff Formation', American Economic Review, 74, 5, 970-85.

Milner, H. V. (1988), Resisting Protectionism: Global Industries and the Politics of International Trade (Princeton, NJ: Princeton University Press).

Milner, H. V. (1997), Interests, Institutions, and Information: Domestic Politics and International Relations (Princeton, NJ: Princeton University Press).

Milner, H. V. and B. P. Rosendorff (1997), 'Democratic Politics and International Trade Negotiations: Elections and Divided Government as Constraints on Trade Liberalization', Journal of Conflict Resolution, 41, 1, 117-46.

Milner, H. V. with K. Kubota (2005), 'Why the Move to Free Trade? Democracy and Trade Policy in the Developing Countries', International Organization, 59, 1, 107-43.

Noguer, M. and M. Siscart (2005), 'Trade Raises Income: A Precise and Robust Result', Journal of International Economics, 65, 2, 447-60.

Nye, J. (1988), 'Neorealism and Neoliberalism', World Politics, 40, 2, 235-51.

Oneal, J. R. and B. Russett (1999), 'Assessing the Liberal Peace with Alternative Specifications: Trade Still Reduces Conflict', Journal of Peace Research, 36, 4, 423-42.

Panagariya, A. (2000), 'Preferential Trade Liberalization: The Traditional Theory and New Developments', Journal of Economic Literature, 38, 2, 287-331.

Panagariya, A. and R. Findlay (1996), 'A Political-Economy Analysis of Free Trade Areas and Customs Unions', in R. Feenstra, G. Grossman, and D. Irwin (eds.), The Political Economy of Trade Reform (Cambridge, MA: MIT Press).

Pevehouse, J. (2005), Democracy from Above: Regional Organizations and Democratization (Cambridge: Cambridge University Press).

Pevehouse, J., T. Nordstrom and K. Warnke (2004), 'The Correlates of War 2 International Governmental Organizations Data Version 2.0', Conflict Management and Peace Science, 21, 2, 101-19.

Richardson, M. (1993), 'Why a Free Trade Area? The Tariff Also Rises', Economics and Politics, 6, 1, 79-96.

Richardson, M. (1994), 'Endogenous Protection and Trade Diversion', Journal of International Economics, 34, 309-24.

Rodriguez, F. and D. Rodrik (2001), 'Trade Policy and Economic Growth: A Skeptic's Guide to the Cross-National Evidence', in B. Bernanke and K. Rogoff (eds.), NBER Macroeconomics Annual 2000 (Cambridge, MA: MIT Press for NBER).

Rodrik, D. (1994), 'The Rush to Free Trade in the Developing World', in S. Haggard and S. B. Webb (eds.), Voting for Reform: Democracy, Political Liberalization, and Economic Adjustment (New York: Oxford University Press).

Schiff, M. (2000), 'Multilateral Trade Liberalization, Political Disintegration, and the Choice of Free Trade Agreements versus Customs Unions', World Bank Policy Research Working Paper No. 2350.

Signorino, C. S. and J. M. Ritter (1999), 'Tau-b or Not Tau-b: Measuring the Similarity of Foreign Policy Positions', International Studies Quarterly, 43, 1, 115-44.

Tsebelis, G. (2002), Veto Players: How Political Institutions Work (Princeton, NJ: Princeton University Press).

Venables, A. (2003), 'Winners and Losers from Regional Integration Agreements', The Economic Journal, 113, 490, 747-62.

Wittman, D. A. (1989), 'Why Democracies Produce Efficient Results', Journal of Political Economy, 97, 6, 1395-424.

Wittman, D. A. (1995), The Myth of Democratic Failure: Why Political Institutions Are Efficient (Chicago: Chicago University Press).

World Trade Organization (WTO) (1995), Regionalism and the World Trading System (Geneva: WTO).

Yarbrough, B. V. and R. M. Yarbrough (1992), Cooperation and Governance in International Trade (Princeton, NJ: Princeton University Press). 